\title{
Reproductive strategies of a population of a freshwater amphipod (Crustacea, Amhipoda, Hyalellidae) from southern Brazil
}

\author{
Daniela da Silva Castiglioni ${ }^{1 *}$ (, , Morgana Taís Streck ${ }^{1}$, Stella Gomes Rodrigues ${ }^{2}$ \& \\ Alessandra Angélica de Padua Bueno ${ }^{2}$ \\ ${ }^{1}$ Universidade Federal de Santa Maria, Departamento de Zootecnia e Ciências Biológicas, Avenida \\ Independência, 3751, Vista Alegre, 97105-900, Palmeira das Missões, RS, Brasil \\ ${ }^{2}$ Universidade Federal de Lavras, 37200-000, Lavras, MG, Brasil \\ *Corresponding author: Daniela da Silva Castiglioni, e-mail: danielacastiglioni@yahoo.com.br
}

CASTIGLIONI, D. S., STRECK, M. T., RODRIGUES, S. G., BUENO, A. A. P. Reproductive strategies of a population of a freshwater amphipod (Crustacea, Amhipoda, Hyalellidae) from southern Brazil. Biota Neotropica. 18(2): e20170470. http://dx.doi.org/10.1590/1676-0611-BN-2017-0470

\begin{abstract}
The aim of this study was to characterize the reproductive strategies of a population of Hyalella bonariensis from southern Brazil. Pairing success, reproductive period of males and females, fecundity, and body size at the onset of reproduction were evaluated. Animals were sampled four times (August 2012, October 2012, January 2013, and April 2013) with the $250 \mu \mathrm{m}$-mesh dip net during 20 minutes by only one person. In the field, precopulatory pairs and ovigerous females were individualized. In the laboratory, cephalothorax length (CL) were measured and eggs and juveniles were removed from the females' marsupium and counted. The mean CL of paired males and females was significantly higher than that of non-paired males and females. A sexual dimorphism in body size was observed in the population - both paired and non-paired males were larger than females. Probably larger males have a higher probability of losing females during precopulatory behavior. A significant correlation was observed between the size of paired males and females - larger males often paired with larger females and smaller males paired with smaller females $(r=0.81)$. The pairing success of males increased with body size and we can assume that males from all size classes are able to find mates. The pairing success of females was independent of body size - paired and non-paired females had similar mean CL. The reproductive success increased with body size in males and females, and was more evident in males. Females from the largest size classes had null reproductive success. The idea that larger females can produce more eggs but might have a lower probability of finding a mate than smaller females was corroborated by our results. Therefore, smaller females have higher pairing success because they are capable of mating with a higher percentage of males. The estimated mean fecundity of $H$. bonariensis was 17.4 $( \pm 3.89)$ eggs/juveniles. Our results are similar to those of other species of Hyalella from Brazil.

Keywords: fecundity, body size, Hyalella bonariensis, reproductive success, pairing success.
\end{abstract}

\section{Estratégias reprodutivas de uma população de um anfípodo de água doce (Crustacea, Amhipoda, Hyalellidae) do sul do Brasil}

\footnotetext{
Resumo: Este trabalho teve por objetivo caracterizar as estratégias reprodutivas de uma população de Hyalella bonariensis no sul do Brasil, avaliando o sucesso de pareamento, o período reprodutivo de machos e fêmeas, a fecundidade e o tamanho corporal dos indivíduos durante a reprodução. Para isso foram realizadas quatro amostragens (Agosto/2012, Outubro/2012, Janeiro/2013 e Abril/2013) utilizando-se uma rede de mão, com malha de $250 \mu \mathrm{m}$, durante 20 minutos por um coletor. Em campo, os casais e as fêmeas ovígeras foram individualizados e em laboratório os mesmos foram mensurados quanto ao comprimento do cefalotórax (CC) ( $\mathrm{mm})$ e os ovos ou juvenis encontrados dentro do marsúpio foram contados. O CC médio dos machos e fêmeas pareados foi significativamente superior ao dos machos e fêmeas não pareados. Um dimorfismo sexual no tamanho corpóreo foi observado na população - ambos machos pareados e não pareados foram maiores do que as fêmeas. Aparentemente os machos maiores têm uma maior probabilidade de perder fêmeas durante o comportamento precopulatório. Foi observada correlação positiva entre o tamanho dos machos e fêmeas que foram encontrados formando casais - machos
} 
maiores geralmente pareiam com fêmeas maiores e machos menores com fêmeas menores $(r=0,81)$. $\mathrm{O}$ sucesso de pareamento dos machos aumentou com o tamanho corpóreo e podemos assumir que os machos de todas as classes de tamanho são capazes de encontrar parceiras sexuais; entretanto, o sucesso de pareamento das fêmeas não depende do tamanho das mesmas, sendo que as fêmeas pareadas e não pareadas apresentaram CC médio semelhante. O sucesso reprodutivo da espécie aumentou com o tamanho corpóreo em machos e fêmeas, sendo mais pronunciado nos machos. As fêmeas pertencentes às maiores classes de tamanho apresentaram sucesso reprodutivo nulo. Os resultados suportam a ideia que as fêmeas grandes poderiam ter uma baixa probabilidade de encontrar parceiro para formar par pré-copulatório, quando comparada às fêmeas de tamanhos inferiores, apesar das fêmeas maiores serem mais fecundas. Neste sentido, as menores fêmeas possuem um sucesso de pareamento maior, pois elas são capazes de copular com uma elevada proporção de machos. A fecundidade média da espécie foi estimada em 17,4 $( \pm 3,89)$ ovos/juvenis. Os resultados observados no presente trabalho assemelham-se aos encontrados para outras espécies do gênero já analisadas no sul do Brasil.

Palavras-chave: fecundidade, Hyalella, sucesso de pareamento, sucesso reprodutivo, tamanho corpóreo.

\section{Introduction}

In general, the reproduction of Amphipoda is well known (Strong 1973; Hartnoll 1982; Sastry 1983; Wellborn 1995; Cothran et al. 2015). The sequential events of reproduction can be summarized in four stages: stage I, location of a mate mediated by pheromones; stage II, pairing initiates through contact stimuli; stage III, male and female pairing persists until the female molts; and stage IV, end of mating shortly after the molt (Borowsky 1991).

The precopulatory behavior is a common feature in some amphipod species. Males carry females on their ventral surface during several days prior female's molting, which signals mating availability (Hynes 1955; Wellborn 1995; Castiglioni \& Bond-Buckup 2007; Castiglioni $\&$ Bond-Buckup 2008b). The precopulatory behavior probably ensures that the male is near when female reaches its short sexual period (Strong 1973; Borowsky 1984). It is also likely that the male protects the female against predators and from other males during the precopulatory period (Strong 1973; Lewbel 1978; Borowsky 1984; Dick et al. 1990). After mating, the development of amphipod crustaceans occurs within the marsupium and can be divided into two stages: 1) from ovulation to hatching (embryonic period) and 2) from hatching to emergence of the litter juvenile) (Borowsky 1980). The amphipods present a direct development, with the pups hatching with the body shape similar to that of the adult (Strong 1972; Borowsky 1991; Steele \& Steele 1991; Morrit \& Spicer 1996; Aoki 1997; Thiel 1999).

Hyalella Smith, 187 is a genus of freshwater crustacean distributed throughout the American continent, and in this genus, pairing, i.e., precopulatory behavior, occurs before copulation and several factors influence its success. Male and female body size, mate selection, and intrinsic factors, such as water temperature, might influence the reproductive success and fecundity of Hyalella (Wellborn 1995; Castiglioni \& Bond-Buckup 2008a).

In Brazil, the studies about reproduction concerning Hyalella are restrict to species from south and southeast regions. In southern Brazil, reproductive features of the sympatric species $H$. castroi Bond-Buckup, Araujo \& Santos, 2008, and H. pleoacuta Bond-Buckup, Araujo \& Santos, 2008 were described (Castiglioni \& Bond-Buckup 2007; Castiglioni \& Bond-Buckup 2008a). In southeastern Brazil, where dry and wet seasons are well-defined, reproduction and egg production of H. carstica Bastos-Pereira \& Bueno, 2012 and H. longistila (Faxon 1876) were evaluated (Torres et al. 2015; Bastos-Pereira \& Bueno 2016).
The species Hyalella bonariensis Bond-Buckup, Araujo \& Santos, 2008 is often found among macrophytes in water courses from southern Brazil and Argentina (Santos et al. 2008; Bueno et al. 2014). Only one study was recently developed on the population dynamics of the species in the municipality of Silveira Martins, central region of the state of Rio Grande do Sul, and it was found that ovigerous females and couples in pre-copulatory behavior were more frequent in the winter (Castiglioni et al. 2016).

The aim of this study is to characterize the reproductive strategy of H. bonariensis from a headwater stream from southern Brazil. Pairing success, reproductive period of males and females, fecundity, and body size onset reproduction were evaluated.

\section{Material and Methods}

The studied population is located in a headwater stream in a private rural property called Portal do Roio (29³9’25.14”S, 5337’33.53”W), in Silveira Martins municipality, central region of state of Rio Grande do Sul, in the southernmost Brazil. Four samplings were conducted in August and October 2012 and January and April 2013. In this region, the weather is, as the Köppen classification system, subtropical "Cfa", with average annual relative humidity of the air $82 \%$ (Isaia 1992). The central region of the state of Rio Grande do Sul is located in the transition area of the geomorphological compartments called Depressão Central e Planalto. According to Moraes \& Bezzi (2009) the Depressão Central is associated with sedimentary rocks such as sandstones, clays and river plains and displays altitude around 90 meters above sea level. The Planalto slope has irregular relief associated with basaltic rocks and the altitude ranges from 500 to 100 meters above sea level (Dantas et al. 2010).

Amphipods use macrophytes as shelters and food so plants from each sample site were collected with a $250 \mu \mathrm{m}$-mesh dip net during 20 minutes by only one person. Afterwards, the macrophytes were stored in plastic bags and transferred to the laboratory in thermic boxes. Ovigerous females and precopulatory pairs were individualized and stored into microtubes with $70 \%$ ethanol.

In the laboratory, all individuals were separated from the macrophytes, identified, separated into to four categories (juveniles, males, females and ovígerous females) (Borowsky 1991; Castiglioni et al. 2016) and measured (cephalothorax length, CL in mm) under the micrometer ocular of a stereomicroscope. 
The mean body size (cephalothorax length in $\mathrm{mm}$ ) of unpaired and paired males were compared with the mean body size of unpaired and paired females, by means of a $t$ test, after checking for the normality and homoscedasticity of the data $(\alpha=0.05)$ (Zar, 1996). Moreover, the mean body size of paired and unpaired amphipods was compared, to assess whether pairing success was influenced by body size ( $t$ test; $\alpha=0.05)$ (Zar, 1996).

To evaluate if $H$. bonariensis have mate preferences, the correlation between CL of paired males and females was estimated with a Person correlation coefficient (r). To evaluate if pairing is influenced by mate size, the mean CL of paired and non-paired males and paired and nonpaired females were compared by a t test $(\alpha=0.05)$. The Pairing Success Index (PSI) was used to evaluate the relationship between pairing success and male and female size. The PSI was adapted by Wellborn (1995) from the relative feeding index (Manly 1974) and have already been used in other studies about Hyalella reproduction (Castiglioni \& Bond-Buckup 2008b), and it is given by

$$
\beta i=(r i / n i) / \sum\left(\frac{r j}{n j}\right) \text { where, }
$$

$\mathrm{i}$ is the relative pairing success in size class $\mathrm{i}$; ri and ni are the proportion of paired and non-paired individuals, respectively. The denominator is the sum of the proportion of paired individuals from all size classes. The minimum CL used for the size classes was the size of the smaller male and female found in precopulatory behavior. The size class intervals were based on $1 / 4$ of the CL standard deviation value (Markus 1971). Considering that the reproductive success also depends on aspects such as the number of fertilized eggs, male reproductive success $(\mathrm{RM}, \mathrm{i})$ was estimated by the following formula:

$$
R M, i=\beta i e i / \sum \beta i e i \text { where }
$$

the number of eggs fertilized by males from size class i (ei) was estimated through the calculation of the expected fecundity of each paired female using the regression of the number of eggs versus the $\mathrm{CL}$ of ovigerous females $(\mathrm{F}=40.668 \mathrm{CL}-4.9461)$. The denominator refers to the sum of the fecundity of all size classes.

Female reproductive success $(\mathrm{RF}, \mathrm{i})$ was derived from egg production, as follows:

$$
R F, i=f i / \sum f j \text { where, }
$$

$f i$ is the observed mean egg production (number of eggs inside the marsupium) of ovigerous females from size class $i$, and the denominator refers to the sum of the fecundity of all size classes. The minimum CL of the size classes was the size of the smallest precopulatory pair.

To estimate fecundity, the marsupial content was categorized into three stages of embryonic development and one post-embryonic stage according to Hynes (1955), Dick et al. (1998), Castiglioni \& Bond-Buckup (2007, 2009). The developmental stages were easily distinguished under stereomicroscope and were characterized as follows: stage I (initial) — orange eggs, completely filled with yolk, and with discrete or no cleavage; stage II (intermediary) - beginning of cell cleavage with well-defined body parts absent; stage III (final) - yolk completely absorbed and reduced to a small portion used for embryonic supply, body somites and eyes visible; and stage IV (juveniles) - newly hatched juveniles attached inside the marsupium.

All eggs and juveniles were removed from the marsupium and counted under a stereomicroscope. The minimum, maximum, and mean number of eggs (from each stage of embryonic development) and juveniles were estimated. The comparison between the mean number of eggs of each stage of embryonic development and juveniles was performed with an analysis of variance (ANOVA), complemented by a Bonferroni test $(\mathrm{F} ; \alpha=0.05)$. The minimum, maximum, and mean fecundity of each season was estimated and compared among seasons with ANOVA, followed by a Bonferroni test (F; $\alpha=0.05)$ (Zar 1996). All ANOVA tests were preceded by assessments of normality and homocedasticity of the data (Zar 1996).

The relationship between ovigerous females CL (x) and the number of eggs per embryonic stage and number of juveniles (y) was estimated through a regression analysis. Then, a Pearson correlation (r) was calculated for each relationship ( $\alpha=0.05)$ (Zar 1996).

\section{Results}

A total of 5,269 individuals of $H$. bonariensis were captured, 1,315 juveniles, 1,879 males, 2,075 females ( 240 ovigerous females). Of that total, 54 pairs were found in precopulatory behavior.

The mean CL of paired males and females was significantly larger than of non-paired males and females (males $\mathrm{t}=10.5$; females $\mathrm{t}=8.67$; $<0.05$; Table 1). A sexual dimorphism in body size was observed in the population; both paired and non-paired males were larger than females (paired males $\mathrm{t}=5.46$; non-paired males $\mathrm{t}=9.80 ; \mathrm{p}<0.05$; Table 1 ).

A positive correlation between the size of males and females found in precopulatory behavior was observed: larger males often paired with larger females and smaller males paired with smaller females $(r=0.81$; Figure 1). Male success in finding a mate increased with body size. Males in larger size classes were approximately 2.5 times more likely of finding a mate than males from smaller size classes (Figure 2). Pairing success also increased with female body size; females from smaller size classes had null pairing success (Figure 2). Additionally, the reproductive success also increased with body size increment in both males and females (Figure 3). However, it seemed that extremely large males had a decreased reproductive and pairing success when compared with intermediate size males (Figure 3).

The cephalothorax length of ovigerous females ranged from 0.32 to $0.74 \mathrm{~mm}$ (mean \pm standard deviation $=0.55 \pm 0.07 \mathrm{~mm}$ ). Females bearing eggs in different stages of embryonic development and those bearing juveniles had similar mean CL ( $\mathrm{p}>0.05$; Table 2$)$.

Female egg/juvenile production ranged from 8 to 26 (17.4 \pm 3.89 eggs/juveniles). The number of eggs produced in each stage of embryonic development and the number of juveniles found inside the marsupium are shown in Table 3. There was a decrease of egg production throughout the embryonic development; the mean number of eggs in stages I, II, and III was significantly higher than that of juveniles inside the marsupium $(p<0.05)$ (Table 3$)$. In all stages of embryonic development, there was positive linear correlation between the number of eggs produced and the CL of ovigerous females $(p<0.05)$. The number of juveniles inside the marsupium also showed positive correlation with female size $(\mathrm{p}<0.05)$ (Table 3$)$. 
Castiglioni, D.S. et al.

Table 1. Minimum, maximum, and mean cephalothorax length $(\mathrm{mm})( \pm$ standard deviation) of Hyalella bonariensis paired and unpaired males and females from Silveira Martins municipality, state of Rio Grande do Sul, Brazil.

\begin{tabular}{lcccc}
\hline & \multicolumn{2}{c}{ Males } & \multicolumn{2}{c}{ Females } \\
\cline { 2 - 5 } & Paired & Unpaired & Paired & Unpaired \\
\hline CL mín - max & $0.40-0.74$ & $0.30-0.92$ & $0.38-0.62$ & $0.30-0.74$ \\
CL mean \pm sd & $0.63 \pm 0.08 \mathrm{a}$ & $0.49 \pm 0.10 \mathrm{~b}$ & $0.54 \pm 0.05 \mathrm{a}$ & $0.46 \pm 0.08 \mathrm{~b}$ \\
$\mathrm{~N}$ & 54 & 1825 & 54 & 2021 \\
\hline
\end{tabular}

Note: Different letters indicate significant difference $(t$ test $)$ between paired and non-paired animals of each $\operatorname{sex}(\mathrm{p}<0.05)$; min $=$ minimum; max $=$ maximum; $\mathrm{sd}=$ standard deviation; $\mathrm{N}=$ number of individuals.

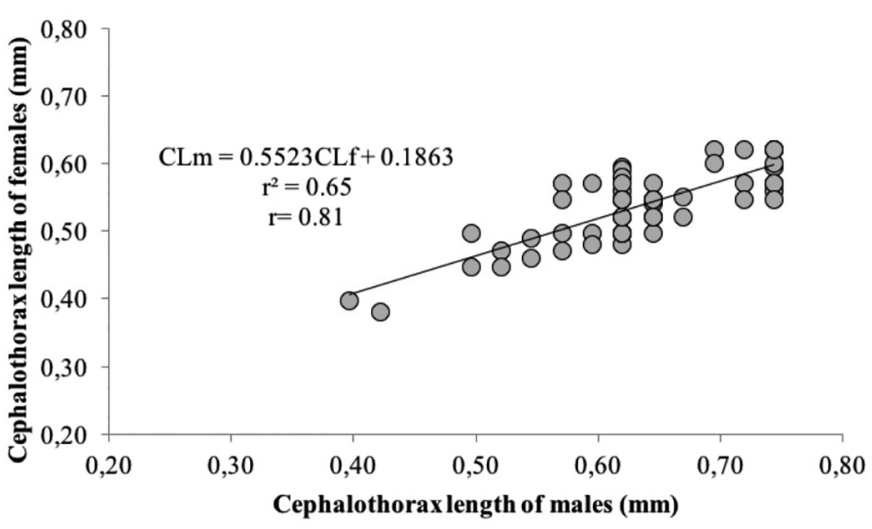

Figure 1. Assortative mating evaluated by Person's correlation between body size (cephalothorax length, in mm) of Hyalella bonariensis paired and non-paired males and females from Silveira Martins municipality, state of Rio Grande do Sul, Brazil.

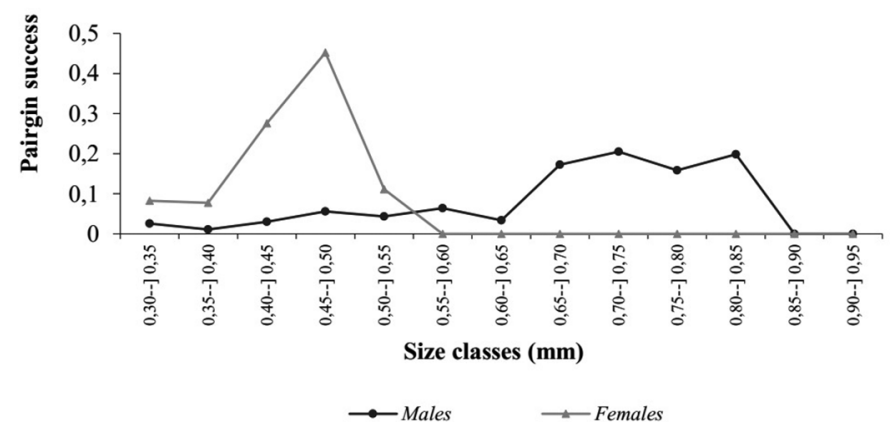

Figure 2. Relationship between pairing success and size (cephalothorax length, in $\mathrm{mm}$ ) of Hyalella bonariensis males from Silveira Martins municipality, state of Rio Grande do Sul, Brazil.

There was a significant reduction of the number of juveniles in the marsupium compared with the number of eggs $(p>0.05)$. Considering the seasonal mean fecundity, egg production was higher in winter and lower in autumn $(\mathrm{p}<0.05$; Table 4 ; juveniles were not included in this analysis). In all seasons, there was a positive correlation between female size and the number of eggs produced, meaning that egg production increased with female size $(p<0.05$; Table 4$)$.

\section{Discussion}

Our observations revealed that paired males and females are larger than non-paired individuals. This finding is also true in populations of the $H$. azteca (Saussure, 1858) species complex from North America (Wellborn \& Bartholf 2005) and in the Brazilian species H. pleoacuta,

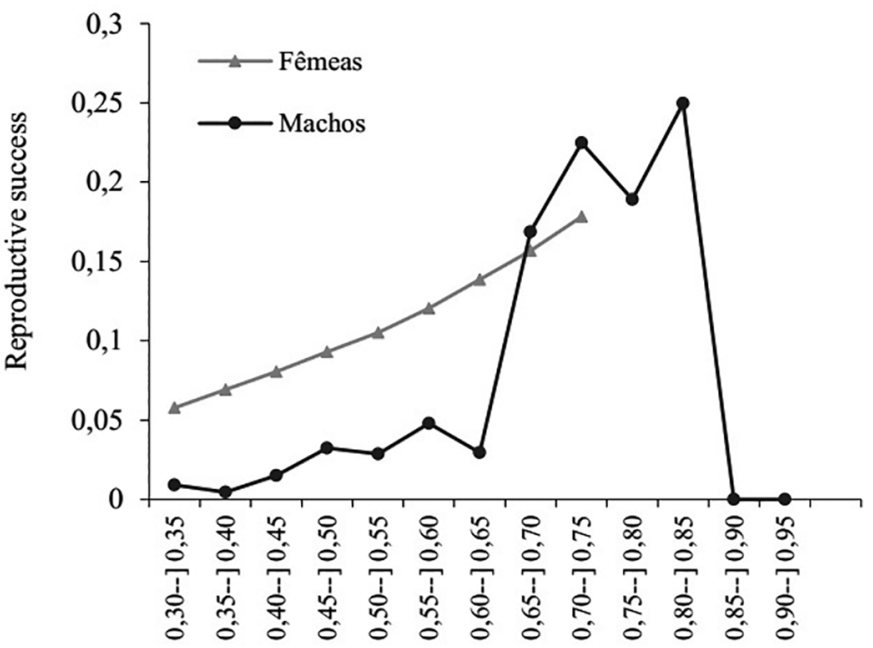

Size classes (mm)

Figure 3. Reproductive success, based on size (cephalothorax length, in $\mathrm{mm}$ ) of Hyalella bonariensis males (RM,i) and females $(\mathrm{RF}, \mathrm{i})$ from Silveira Martins municipality, state of Rio Grande do Sul, Brazil.

Table 2. Minimum, maximum, and mean cephalothorax length ( $\mathrm{mm}$ ) of Hyalella bonariensis females bearing eggs in different stages of embryonic development. Animals collected in Silveira Martins municipality, state of Rio Grande do Sul, Brazil.

\begin{tabular}{llcc}
\hline Stage & $\mathbf{N}$ & Mean \pm sd & Min - Max \\
\hline Initial & 57 & $0.54 \pm 0.07 \mathrm{a}$ & $0.32-0.75$ \\
Intermediary & 49 & $0.55 \pm 0.08 \mathrm{a}$ & $0.32-0.74$ \\
Final & 16 & $0.55 \pm 0.09 \mathrm{a}$ & $0.52-0.67$ \\
Juvenile & 12 & $0.55 \pm 0.09 \mathrm{a}$ & $0.32-0.74$
\end{tabular}

Note: $\mathrm{N}=$ number of females bearing eggs; $\min =$ minimum cephalothorax length; $\max =$ maximum cephalothorax length. Values with at least one letter in common are not significantly different (ANOVA and Bonferroni; $\alpha=0.05$ ).

Table 3. Minimum, maximum, and mean ( \pm standard deviation) number of eggs in each stage of embryonic development and juveniles found in the marsupium of Hyalella bonariensis females from Silveira Martins municipality, state of Rio Grande do Sul, Brazil.

\begin{tabular}{lcccc}
\hline Stage & $\mathbf{N}$ & Mean $\pm \mathbf{s d}$ & Min - Max & $\mathbf{r}^{2}$ \\
\hline Initial & 57 & $16.8 \pm 3.5 \mathrm{a}$ & $8-26$ & 0.75 \\
Intermediary & 49 & $17.4 \pm 4.0 \mathrm{a}$ & $9-25$ & 0.79 \\
Final & 16 & $17.2 \pm 4.9 \mathrm{a}$ & $14-26$ & 0.87 \\
Juvenile & 12 & $14.7 \pm 0.09 \mathrm{~b}$ & $12-17$ & 0.80 \\
\hline
\end{tabular}

Note: $\mathrm{N}=$ number of females bearing eggs; $\min =$ minimum number of eggs; $\max =$ maximum number of eggs. Values with at least one letter in common are not significantly different (ANOVA and Bonferroni, $\alpha=0.05$ ). 
Table 4. Minimum, maximum, and mean ( \pm standard deviation) number of eggs inside the marsupium of Hyalella bonariensis females in each season in Silveira Martins municipality, state of Rio Grande do Sul, Brazil.

\begin{tabular}{lcccc}
\hline Stage & $\mathbf{N}$ & Mean $\pm \mathbf{s d}$ & Min - Max & $\mathbf{r}^{2}$ \\
\hline Autunm & 31 & $14.1 \pm 2.6 \mathrm{c}$ & $9-20$ & 0.74 \\
Winter & 41 & $19.3 \pm 3.1 \mathrm{a}$ & $12-26$ & 0.68 \\
Spring & 20 & $17.9 \pm 4.6 \mathrm{~b}$ & $8-23$ & 0.90 \\
Summer & 24 & $17.1 \pm 3.3 \mathrm{~b}$ & $13-25$ & 0.94 \\
\hline
\end{tabular}

Note: $\mathrm{N}=$ number of females bearing eggs; $\mathrm{min}=$ minimum number of eggs; $\max =$ maximum number of eggs. Values with at least one letter in common are not significantly different (ANOVA and Bonferroni, $\alpha=0.05$ ).

H. castroi (Castiglioni \& Bond-Buckup 2007, 2008b), and H. longistila (Bastos-Pereira \& Bueno 2016). According to Ward (1983) and Dick \& Elwood (1990), larger males have a lower probability of losing females during precopulatory behavior. This statement would explain why paired males were significantly larger than non-paired males in our study; similar results were also observed in populations of $H$. pleoacuta and H. castroi (Castiglioni \& Bond-Buckup 2008b), and H. longistila (Bastos-Pereira \& Bueno 2016).

The number of pairs in precopulatory behavior in the population of $H$. bonariensis was low, when compared to unpaired adults. The same result was observed in $H$. castroi and $H$. pleoacuta by Castiglioni \& Bond-Buckup (2008b) and H. carstica by Torres et al. (2010). Probably the low occurrence of pairs can be related to the fact that the males and females stay in precopulatory behavior for approximately 3 days, a short time (personal observation), since this reproductive behavior can make individuals more vulnerable to predation (Wellborn, 1995). Moreover, the paired amphipods swim lower than unpaired ones (Cothran, 2004), or sampled methods may have led to the separation of males and females (Wellborn 1995; Castiglioni \& Bond-Buckup 2008b).

The studied population of $H$. bonariensis reached sexual maturity at a quite small size. Individuals found in precopulatory behavior were relatively small (males: $0.40 \mathrm{~mm}$ of $\mathrm{CL}$; females: $0.38 \mathrm{~mm}$ of $\mathrm{CL}$ ) in comparison with the maximum size found in general population (male: $0.92 \mathrm{~mm}$ of CL; females: $0.74 \mathrm{~mm}$ of CL). Based on these results we can assume that $H$. bonariensis is able to reproduce early in life. Amphipod species which ensure progeny early in their life cycles may have developed a reproductive strategy aimed at reducing predation risk, since larger individuals are more easily seen by predators (Wellborn 1994, 1995, 2002). Species living in environments with unstable conditions, such as prolonged drought or floods can also reach early sexual maturity to ensure reproduction (Wellborn 1994, 1995, 2002; Appadoo \& Myers 2004).

We observed that paired and non-paired males were larger than paired and non-paired females; similar results were found in populations of H. pleoacuta and H. castroi (Castiglioni \& Bond-Buckup 2008a, b). Amphipod males often direct energy towards copulation, while females allocate time and energy to offspring care, especially in the production of large gametes. It is important to point out that females do not molt during incubation, creating a sexual dimorphism in body size (Wen 1992; Cardoso \& Veloso 1996). As a consequence of this reproductive system, females reach a smaller body size compared with most amphipods - e.g., species of Hyalella such as H. azteca (Geisler
1944; Wen 1992; Othman \& Pascoe 2001), H. pleocuta and H. castroi (Castiglioni \& Bond-Buckup 2008a); and other amphipods such as Gammarus pulex (Linnaeus, 1758) (Adams \& Greenwood 1983), Pseudorchestoidea brasiliensis (Dana, 1853) (Cardoso \& Veloso 1996), Gammarus leopoliensis (Jazdzewski \& Konopacka, 1989) (Zielinski 1998), G. locusta Linnaeus, 1758 (Costa \& Costa 1999), and Echinogammarus longisetosus Pinkster, 1973 (Guerao 2003).

A positive size assortative mating was observed in the population of $H$. bonariensis, i.e., large males paired with large females. This size correlation was also observed in populations of $H$. pleoacuta and $H$. castroi (Castiglioni \& Bond-Buckup 2009), H. azteca (Wellborn 1995), and H. longistila (Bastos-Pereira \& Bueno 2016). Several hypotheses have been proposed to explain this size correlation in mating: loading constraint (Adams \& Greenwood 1983); spatial segregation (Birkehead \& Clarkson 1980); sexual selection (Ward 1984); guarding time (Elwood et al. 1987); microhabitat segregation (Ward \& Porter 1993); and physical constraints (Adams \& Greenwood 1987; Adams et al. 1989; Hatcher \& Dunn 1997). The most accepted hypothesis is male-male competition, which postulates that large males have competitive advantages in pairing with larger and more fecund females (Ward 1983; Ward 1986; Ward 1988; Elwood et al. 1987; Crespi 1989; Dick \& Elwood 1996; Bollache et al. 2000).

The pairing success of $H$. bonariensis increased with male body size and a similar pattern was also recorded in $H$. pleoacuta, $H$. castroi (Castiglioni \& Bond-Buckup 2008b), H. azteca (Wellborn 1995), H. longistila (Bastos-Pereira \& Bueno 2016), and Gammarus pulex (Ward 1988). Therefore, we can assume that males from all size classes are able to find mates. However, although larger females of H. bonariensis are more fecund than smaller females, they may have a lower probability of finding an available mate, because males have difficulty carrying them during pre-copulatory behavior. Because of that, larger females pair with less males, while smaller females can find more males to copulate with (Wellborn 1995). Wellborn (1995) observed that pairing and reproductive success of $H$. azteca is higher in females from intermediate size classes. These results demonstrate that the pairing system of $H$. bonariensis is explained by the loading constrain hypothesis, as observed for $H$. pleoacuta and $H$. castroi (Castiglioni \& Bond-Buckup 2007).

In several crustacean's groups, eggs produced by females in a single brood have synchronized embryonic development, reinforcing the assumption that fertilization occurs in one unique event after pair separation (Green 1965; Kevrekidis 2005). This pattern was recorded here in H. bonariensis and in populations of $H$. pleoacuta, H. castroi (Castiglioni \& Bond-Buckup 2007, 2009), H. longistila (BastosPereira \& Bueno 2016), Gammarus duebeni Lilljeborg, 1852 (Sheader 1983), G. insensibilis Stock, 1966 (Sheader 1996), Pseudorchestoidea brasiliensis (Cardoso \& Veloso 2001), Corophium insidiosum (Crawford, 1937) (Kevrekidis 2004), and C. orientale Schellenberg, 1928 (Kevrekidis 2005).

During the embryonic development of amphipods, it is common to observe a reduction of the embryo number per brood (Moore 1981; Williams 1978; Dick et al. 1998; Dick et al. 2002; Kevrekidis 2004; Castiglioni \& Bond-Buckup 2009; Bastos-Pereira \& Bueno 2016); this was the case for H. bonariensis. According to Koch (1990), 
as the embryo volume increases, the space inside the marsupium decreases, leading to a premature loss of a few embryos. Apparently, this occurs due to a higher embryo production than the marsupium can hold during the final stages of development. Also, the reduction of eggs/juveniles may be a consequence of the presence of parasites (Sheader 1983; Kuris 1991) or maternal cannibalism, which may occur when food resources are scarce (Sheader 1983; Castiglioni \& Bond-Buckup 2009).

A positive correlation between the female size and the number of eggs/juveniles was observed in H. bonariensis. Several authors observed an association between females' size/weight and the number of embryos in other Hyalella species (Strong 1972; Othman \& Pascoe 2001; Alcocer et al. 2002; Castiglioni \& Bond-Buckup 2007, 2009; Torres et al. 2015; Bastos-Pereira \& Bueno 2016). According to Hines (1988), this association may be linked to the fact that the egg mass is restricted by the space available for energetic accumulation and gonadal development. In each species, the wide variability of the carapace shape may interfere with the volume available for gonadal development and, consequently, in brood size. Therefore, egg mass and body cavity volume have similar allometry (Hines 1982).

Production of many small eggs in the summer and few large eggs in the winter is a common amphipod reproductive strategy (Steele and Steele 1969; Sheader 1978; Kolding and Fenchel 1981; Powell 1992), reflecting both seasonal change in the reproductive investment of females that may be related to seasonal changes in food availability, and female and offspring mortality (Price 1974; Smith and Fretwell 1974). However, $H$. bonariensis showed a contrasting reproductive pattern to most species, producing fewer eggs during the summer and many in the winter. Probably, these fluctuations in number of eggs appear to be related to the macrophyte cover, which is much depleted during the warmer months (personal observation), reducing the food and shelter available for breeding females, but may also contributing to increased mortality of recruits. A similar reproductive strategy, characterized by the production of small broods during summer, has been observed in other species of amphipods, such as $H$. pleocuta and $H$. castroi (Castiglioni \& Bond-Buckup 2009), Bathyporeia pilosa Lindström, 1855 (Powell 1992) and Gammarus locusta (Linnaeus, 1758 (Costa and Costa 1999).

The number of eggs produced by $H$. bonariensis is lower than in other Hyalella species from southern Brazil (H. castroi and H. pleocuta) (Table 5). Hyalella castroi and H. pleocuta are found in aquaculture trout pounds and have constant food availability, so females have sufficient energetic input to produce a high number of eggs (Castiglioni $\&$ Bond-Buckup 2009). However, H. bonariensis has a higher fecundity in comparison with other tropical species from southeast Brazil and with the North American species H. azteca. Distinct fecundities between species might be a consequence of differences in habitats and the microclimate in which they live, as it has been already observed in other amphipod species (Poweel 1992; Appadoo \& Myers 2004). The high number of eggs produced by $H$. bonariensis might be an attempt to optimize juvenile survival since the mortality rate is elevated during this stage. However, fecundity data from species raised in laboratory would be needed to confirm this assumption.
Table 5. Comparative fecundity different species of Hyalella (data obtained from literature).

\begin{tabular}{|c|c|c|}
\hline Species & NE & Authors \\
\hline Hyalella azteca & $1-50 \bullet$ & Cooper (1965) \\
\hline Hyalella sp. & $1-6^{\bullet}$ & Sampaio (1988) \\
\hline Hyalella azteca & $18.0 *$ & Pennak (1953) \\
\hline $\begin{array}{l}\text { Hyalella pernix } \\
(=H . \text { curvispina })\end{array}$ & $13.0 *$ & Severo (1997) \\
\hline Hyalella sp. & $31.3 *$ & Morelli (2001) \\
\hline Hyalella azteca & $1-38 \bullet$ & Alcocer et al. (2002) \\
\hline Hyalella azteca & $9.0^{*}$ & Othman \& Pascoe (2001) \\
\hline Hyalella azteca & $5.2 *$ & Wellborn et al. (2005) \\
\hline Hyalella azteca & $5.3 *$ & Wellborn et al. (2005) \\
\hline Hyalella azteca & $6.2 *$ & Wellborn et al. (2005) \\
\hline Hyalella azteca & $5.2 *$ & Wellborn et al. (2005) \\
\hline Hyalella azteca & $19.2 *$ & Wellborn et al. (2005) \\
\hline Hyalella azteca & $14.7 *$ & Wellborn et al. (2005) \\
\hline Hyalella azteca & $10.3^{*}$ & Wellborn et al. (2005) \\
\hline Hyalella pleoacuta & $36.1^{*}$ & Castiglioni and Bond-Buckup (2009) \\
\hline Hyalella castroi & $31.4^{*}$ & Castiglioni and Bond-Buckup (2009) \\
\hline Hyalella carstica & $12.6^{*}$ & Torres et al. (2015) \\
\hline Hyalella longistila & $12.8^{*}$ & Bastos-Pereira and Bueno (2016) \\
\hline Hyalella bonariensis & $17.4 *$ & Present study \\
\hline
\end{tabular}

Note: $\mathrm{NE}=$ number of eggs; $\bullet$ indicates minimum and maximum fecundity; * indicates mean fecundity.

\section{Conclusions}

The present paper demonstrated the importance of male body size as a determinant of reproductive success of Hyalella bonariensis similar to other species of genus. Understanding the interactive effects of partner selection, what stimuli are involved, and the evolution of these choices within the genre, including the formulation of predictive models, will be needed to complement studies on reproduction of this crustacean.

\section{Acknowledgements}

This research was funded by Conselho Nacional de Desenvolvimento Científico e Tecnológico - Brasil (CNPq - Process No 477554/2011-3). DSC and MTS are grateful to the Coordenação de Aperfeiçoamento de Pessoal de Nível Superior (CAPES) and CNPq (Process $n^{\circ}$ $55.2597 / 2011-2)$ for the financial support.

\section{Author Contributions}

Daniela da Silva Castiglioni: Contribution in the concept and design of the study.

Morgana Taís Streck: Contribution to data collection.

Stella Gomes Rodrigues: Contribution to manuscript preparation.

Alessandra Angélica de Padua Bueno: Contribution to critical revision, adding intelectual contente. 


\section{Conflicts of interest}

The authors declare that they have no conflict of interest related to the publication of this manuscript.

\section{References}

ADAMS, J. \& GREENWOOD, P.J. 1983. Why are males bigger than females in pre-copula pairs of Gammarus pulex? Behav. Ecol. Sociobiol. 13: 239-241. doi:10.1007/BF00299670.

ADAMS, J. \& GREENWOOD, P.J. 1987. Loading constraints, sexual selection and assortative mating in peracarid Crustacea. J. Zool. 211: 35-46. doi: 10.1111/j.1469-7998.1987.tb07451.x.

ADAMS, J., WATT, P.J., NAYLOR, C.J. \& GREENWOOD, P.J. 1989. Loading constraints, body size and mating preference in Gammarus species. Hydrobiologia. 183: 157-164. doi: 10.1007/BF00018720.

ALCOCER, J., ESCOBAR-BRIONES, E., PERALTA, L. \& ÁlVAREZ, F. 2002. Population structure of the macrobenthic amphipod Hyalella azteca Saussure (Crustacea: Peracarida) on the littoral zone of six crater lakes. In Modern Approaches to the Study of Crustacea (E. Escobar-Briones \& F. Álvarez, eds.). Kluwer Academic/Plenum Plublishers, New York, p.111-115.

ARNQVIST, G. \& ROWE, L. 1995. Sexual conflict and arms races between the sexes - a morphological adaptation for control of mating in a female insect. Proc. R. Soc. Lond. B 261:123-127.

AOKI, N. 1997. Comparative study of mother-young association in caprellid amphipods: is maternal care effective? J. Crust. Biol. 17: 447-458.

APPADOO, C. \& MYERS, A.A. 2004. Reproductive bionomics and life history traits of three gammaridean amphipods, Cymadusa filosa Savigny, Ampithoe laxipodus Appadoo and Myers and Mallacoota schellenbergi Ledoyer from tropical Indian Ocean (Mauritius). Acta Oecol. 26: 227-238. doi:10.1016/j. actao.2004.06.002.

BASTOS-PEREIRA, R. \& BUENO, A.A.P. 2016. Reproductive biology and egg production of Hyalella longistyla (Faxon, 1876) (Amphipoda: Hyalellidae), a freshwater amphipod in southeastern Brazil. J. Crust. Biol. 36(5): 724-730. doi: 10.1163/1937240X-00002465.

BIRKHEAD, T.R. \& CLARKSONV, K. 1980. Mate selection and precopulatory guarding in Gammarus pulex. Z. Tierpsychol. 52: 365-380.

BOLLACHE, L., GAMBADE, G. \& CÉZILLYC, F. 2000. The influence of microhabitat segregation on size-assortative pairing in Gammarus pulex (L.) (Crustacea: Amphipoda). Arch. Hydrobiol. 147: 547-558. doi: 10.1127/ archiv-hydrobiol/147/2000/547.

BOROWSKY, B. 1980. Reproductive patterns of three intertidal salt-marsh gammaridean amphipods. Mar. Biol.55: 327-334.

BOROWSKY, B. 1984. Effects of receptive females's secretions on some male reproductive behaviors in the amphipods Microdeutopus gryllotalpa. Mar. Biol. 84: 183-187 doi:10.1007/BF00393003.

BOROWSKY, B. 1991. Patterns of reproduction of some amphipod crustaceans and insights into the nature of their stimuli. In Crustacean Sexual Biology (R.T. Bauer \& W. Martin, eds). Columbia University Press, New York, pp33-66.

BUENO, A.A.P., RODRIGUES, S.G. \& ARAUJO, P.B. 2014. O estado da arte do gênero Hyalella Smith, 1874 (Crustacea, Amphipoda, Senticaudata, Hyalellidae) no Brasil. In Tópicos de Atualização em Ciências Aquáticas (C. Hayashi, ed.) UFTM, Uberaba, p. 57-88.

CARDOSO, R.S. \& VELOSO, V.G. 1996. Population biology and secondary production of the sandhopper Pseudorchestoidea brasiliensis (Amphipoda: Talitridae) at Prainha Beach, Brazil. Mar. Ecol. Prog. Ser. 142: 111-119.

CARDOSO, R.S. \& VELOSO, V.G. 2001. Embryonic development and reproductive strategy of Pseudorchestoidea brasiliensis (Amphipoda: Talitridae) at Prainha Beach, Brazil. J. Nat. Hist. 35: 201-211. doi: 10.1080/00222930150215332.

CASTIGLIONI, D.S. \& BOND-BUCKUP, G. 2007. Reproductive strategies of two sympatric species of Hyalella Smith, 1874 (Amphipoda, Dogielinotidae) in laboratory conditions. J. Nat. Hist. 41(25-28): 1571-1584. doi: $10.1080 / 00222930701464604$.
CASTIGLIONI, D.S. \& BOND-BUCKUP, G. 2008a. Ecological traits of two sympatric species of Hyalella Smith, 1874 (Crustacea, Amphipoda, Dogielinotidae) from southern Brazil. Acta Oecol. 33: 36-48.

CASTIGLIONI, D.S. \& BOND-BUCKUP, G. 2008b. Pairing and reproductive success in two sympatric species of Hyalella Smith, 1874 (Crustacea, Amphipoda, Dogielinotidae) from southern Brazil. Acta Oecol. 33: 49-55.

CASTIGLIONI, D.S. \& BOND-BUCKUP, G. 2009. Egg production of two sympatric species of Hyalella Smith, 1874 (Crustacea, Amphipoda, Dogielinotidae) in aquaculture ponds in southern Brazil. J. Nat. Hist. 43(2124): 1273-1289. doi: 10.1080/00222930902903756.

COSTA, F.O. \& COSTA, M.H. 1999. Life history of the amphipod Gammarus locusta in the Sado estuary (Portugal). Acta Oecol. 20(4): 305-314. doi 10.1016/S1146-609X(99)00136-8.

COTHRAN, R.D., FRENCH, B.J. \& RELYEA, R.A. 2015. An assessment of Putative Sexually Antagonistic Traits in a Freshwater Amphipod Species. Ethology 121: 740-748. doi: 10.1111/eth.12389.

CRESPI, B.J. 1989. Causes of assortative mating in arthropods. Anim. Behav. 38: $980-1000$.

DANTAS, M.E., VIEIRO, A.C. \& SILVA, D.R.A. 2010. Origem das paisagens. Pp. 35-50. In: VIEIRO, A.C. \& Da SILVA, D.R.A. (Eds). Geodiversidade do estado do Rio Grande do Sul. CPRM, Porto Alegre, $250 \mathrm{p}$.

DICK, J.T.A. \& ELWOOD, R.W. 1990. Symmetrical assessment of females quality by male Gammarus pulex (Amphipoda) during struggles over precopula females. Anim. Behav. 40: 877-883.

DICK, J.T.A. \& ELWOOD, R.W. 1996. Effects of natural variation in sex ratio and habitat structure on mate-guarding decisions in amphipods (Crustacea). Behaviour 133: 985-996.

DICK, J.T.A., IRVINE, D.E. \& ELWOOD, R.W. 1990. Differential predation by males on moulted females may explain the competitive displacement of Gammarus duebeni by G. pulex (Amphipoda). Behav. Ecol. Sociobiol. 26: 41-45. doi: 10.1007/BF00174023.

DICK, J.T.A., BAILEY, R.J.E. \& ELWOOD, R.W. 2002. Maternal care in the rockpool amphipod Apherusa jurinei: developmental and environmental cues. Anim. Behav. 63: 707-713. doi: 10.1006/anbe.2001.1958.

DICK, J.T.A., FALOON, S.E. \& ELWOOD, R.W. 1998. Active brood care in an amphipod: influences of embryonic development, temperature and oxygen. Anim. Behav. 56: 663-672.

ELWOOD, R.W., GIBSON, J. \& NEIL, S. 1987. The amorous Gammarus: size assortative mating in G. pulex. Anim. Behav. 35: 1-6.

GEISLER, S.S.J. 1944. Studies on the postembryonic development of Hyalella azteca (Saussure). Biol. Bull. 86: 6-22.

GREEN, J. 1965. Chemical embryology of the Crustacea. Biol. Rev. Camb. Philos. Soc. 40: 580-600.

GUERAO, G. 2003. Some observations on the life history of the freshwater amphipod Echinogammarus longisetosus Pinkter, 1973 (Gammaridae) from Catalonia (Spain, N Iberian Peninsula). Anim. Biodivers. Conserv. 26(1): 31-39.

HARTNOLL, R.G. 1982. Growth. In The biology of Crustacea: morphology and genetics (D.E. Bliss, ed.). London Academic Press, London, p. 111-196.

HATCHER, M.J. \& DUNN, A.M. 1997. Size and pairing success in Gammarus duebeni: can females be too big? Anim. Behav. 54: 1301-1308. doi: 0003-3472/97/111301+08 \$25.00/0/ar970534.

HINES, A.H. 1982. Allometric constraints and variables of reproductive effort in Brachyuran crabs. Mar. Biol. 69: 309-320. doi: 10.1007/BF00397496.

HINES, A.H. 1988. Fecundity and reproductive output in two species of deep-sea crabs, Geryon fenneri and Geryon quinquedens (Decapoda: Brachyura). J. Crust. Biol. 8(4): 557-562.

HYNES, H.B.N. 1955. The reproductive cycle of some British freshwater gammaridae. J. Anim. Ecol. 24(2): 352-387.

ISAÍA, T. 1992. Planejamento de uso da terra para o município de Santa Maria-RS, através do diagnóstico físico conservacionista das microbacias hidrográficas. UFSM, Santa Maria, $60 \mathrm{p}$ 
KEVREKIDIS, T. 2004. Population dynamics, growth and reproduction of Corophium insidiosum (Crustacea: Amphipoda) at low salinities in Monolimni lagoon (Evros Delta, north Aegean Sea). Hydrobiologia 522: 117-132. doi: 10.1023/B:HYDR.0000029971.11713.41.

KEVREKIDIS, T. 2005. Life history, aspects of reproductive biology and production of Corophium orientale (Crustacea: Amphipoda) in Monolimni lagoon (Evros Delta, north Aegean Sea). Hydrobiologia 537-53-70. doi:10.1007/s10750-004-1713-5.

KOCH, H. 1990. Aspects of the population biology of Traskorchestia traskiana (Stimpson, 1857) (Amphipoda, Talitridae) in the Pacific Northwest, USA. Crustaceana 59: 35-52 doi: 10.1163/156854090X00273.

KOLDING, S. \& FENCHEL, T.M. 1981. Patterns of reproduction in different populations of five species of the amphipod genus Gammarus. Oikos 37: 167-172.

KURIS, A.M. 1991. A review of patterns and causes of crustacean brood mortality. In Crustacean Issues 7: Crustacean Egg Production (A. Wenner \& A. Kuris, eds) Balkema Academic, Rotterdam, p.117-141.

LEWBEL, G.S. 1978. Sexual dimorphism and intraspecific aggression, and their relationship to sex ratios in Caprella gorgonia Laubitz \& Lewbel (Crustacea: Amphipoda: Caprellidae). J. Exp. Mar. Biol. Ecol. 33: 133-151. doi: 10.1016/0022-0981(78)90004-7.

MANLY, B.F.J 1974. A model for certain types of selection experiments. Biometrics 30: 281-294. doi: 10.2307/2529649.

MARKUS, R. 1971. Elementos de estatística aplicada. Faculdade de Agronomia e Veterinária da UFRGS: Centro Acadêmico Leopoldo Cortez, Porto Alegre.

MOORE, P.G. 1981. The life histories of the amphipods Lembos websteri Bate and Corophium bonnellii Milne Edwards in Kelp holdfasts. J. Exp. Mar. Biol. Ecol. 49: 1-50.

MORAES, F. D. \& BEZZI, M. L. 2009. A organização do estado agrário de Mata/RS: a cadeia produtiva da pecuária. Geografia: Ensino \& Pesquisa, 3(2): 21-32.

MORRIT, D. \& J.I. SPICER. 1996. The culture of eggs and embryos of amphipod crustaceans: implications for brood pouch physiology. J. mar. biol. Ass. U.K. 76: 361-376.

POWELL, R. 1992. Biometry of brooding in seven species of amphipods (Crustacea) from the Clyde sea area. J. Nat. Hist. 26: 353-371.

OTHMAN, M.S. \& PASCOE, D. 2001. Growth, development and reproduction of Hyalella azteca (Saussure, 1858) in laboratory culture. Crustaceana 74(2): 171-181. doi: 10.1163/156854001750096274.

PENNAK, R.N. 1953. Freshwater invertebrates of the United States. Ronald Press Company, New York.

PRICE, P.W. 1974. Strategies for eggs production. Evolution 28: 76-84.

SASTRY, A.N. 1983. Ecological aspects of reproduction. In The biology of Crustacea: enviromental adaptations (F.J. Vernberg \& W.B. Vernberg eds.). Academic Press, New York, p. 179-269.

SANTOS, A.L.F., ARAUJO, P.B. \& BOND-BUCKUP, G. 2008. New species and new reports of Hyalella (Crustacea, Amphipoda, Dogielinotidae) from Argentina. Zootaxa, 1760, 24-36.

SHEADER, M. 1978. Distribution and reproductive biology of Corophium insidiosum (Amphipoda) on the north-east coast of England. J. Mar. Biol. Assoc. U. K. 58: 585-596.

SHEADER, M. 1983. The reproductive biology and ecology of Gammarus duebeni (Crustacea: Amphipoda) in southern England. J. Mar. Biol. Assoc. U.K. 63: 517-540 doi: 10.1017/S0025315400070855.
SHEADER, M. 1996. Factors influencing egg size in the gammarid amphipod Gammarus insensibilis. Mar. Biol. 124: 519-526. doi: 10.1007/BF00351033.

SMITH, C.C. \& FRETWELL, S.D. 1974. The optimal balance between size and number of offspring. Am. Nat. 108: 499-506.

STEELE, D.H. \& STEELE, V.J. 1969. The biology of Gammarus (Crustacea, Amphipoda) in the North-western Atlantic. I. Gammarus duebeni Lillj. Can. J. Zool. 47: 235-244.

STEELE, D.H. \& V.J. STEELE. 1991. Morphological and environmental restraints on egg production in amphipods. In: BAUER, R.T. \& W.J. MARTIN. J. Crust. Sex. Biol. 157-170.

STRONG, D.R. 1972. Life history variation among populations of an amphipod (Hyalella azteca). Ecology 53(6): 1103-1111. doi: 10.2307/1935422.

STRONG, D.R. 1973. Amphipod amplexus, the significance of ecotypic variation. Ecology. 5: 1383-1388. doi: 10.2307/1934203.

THIEL, M. 1999. Extended parental care behavior I crustaceans - a comparative overview. Crustacean Issues 12: 211-226.

TORRES, S.H.S., BASTOS-PEREIRA, R. \& BUENO, A.P.P. 2015. Reproductive aspects of Hyalella carstica (Amphipoda: Hyalellidae) in a natural environment in southeastern Brazil. Nauplius 23 (2): 159-165. doi: $10.1590 / \mathrm{S} 0104-64972015002325$.

WARD, P.I. \& PORTER, A.H. 1993. The relative roles of habitat structure and male-male competition in the mating system of Gammarus pulex (Crustacea, Amphipoda): a simulation study. Anim. Behav. 45: 119-133. doi: 10.1006/ anbe.1993.1011.

WARD, P.I. 1983. Advantages and a disadvantage of large size for male Gammarus pulex (Crustacea: Amphipoda). Behav. Ecol. Sociobiol. 14: 69-76. doi: 10.1007/BF00366658.

WARD, P.I. 1984. The effects of size on the mating decision of Gammarus pulex (Crustacea: Amphipoda). Z. Tierpsychol. 64: 174-184. doi: 10.1111/j.14390310.1984.tb00358.x.

WARD, P.I. 1986. A comparative study of the breeding behaviour of a stream and a pond of Gammarus pulex (Amphipoda). Oikos 46: 29-36. doi: $10.2307 / 3565376$

WARD, P.I. 1988. Sexual selection, natural selection and body size in Gammarus pulex (Amphipoda). Am. Nat. 131: 348-359.

WELLBORN, G.A. 1994. Size-biased predation and prey life histories: a comparative study of freshwater amphipod populations. Ecology 75(7): 2104-2117 doi: 10.2307/1941614.

WELLBORN, G.A. 1995. Determinants of reproductive success in freshwater amphipod species that experience different mortality regimes. Anim. Behav. 50: 353-363. doi: 10.1006/anbe.1995.0251.

WELLBORN, G.A. 2002. Trade-off between competitive ability and antipredator adaptation in a freshwater amphipod species complex. Ecology 83(1): 129-136.

WELLBORN, G.A. \& BARTHOLF, S.E. 2005. Ecological context and the importance of body and gnathopod size for pairing in two amphipod ecomorphs. Oecologia 143: 308-316. doi: 10.1007/s00442-004-1786-x.

WEN, Y.H. 1992. Sexual dimorphism and mate choice in Hyalella azteca (Amphipoda). Am. Midl. Nat. 129: 153-160.

WILLIAMS, J.A. 1978. The annual pattern of reproduction of Talitrus saltator (Crustacea: Amphipoda: Talitridae). J. Zool. 184: 213-244.

ZAR, J.H. 1996. Biostatistical analysis. Prentice Hall, Upper Saddle River.

ZIELINSKI, D. 1998. Life cycle and altitude range of Gammarus leopoliensis Jazdzewski \& Konopacka, 1989 (Amphipoda) in south-eastern Poland. Crustaceana 71(2): 129-143. doi: 10.1163/156854098X00112. 